\title{
Perubahan Kadar Hormon Testosteron dan Progesteron, Korelasinya dengan Indeks Gonado Somatik dan Tingkat Kematangan Gonad pada Ikan Brek (Puntius orphoides Cuvier \& Valenciennes, 1842)
}

\section{Changes in Testoteron and Progresteron Content, and its Correlation with Gonado Somatic Indices and Gonad Maturity on Red Cheek Barb (Puntius orphoides Cuvier \& Valenciennes, 1842)}

\author{
Suhestri Suryaningsih $^{1 *}$, Mammed Sagi ${ }^{2}$, Kamiso H.N. ${ }^{3}$, dan Suwarno Hadisusanto ${ }^{2}$ \\ ${ }^{1}$ Prodi Biologi-Program Pascasarjana Universitas Gadjah Mada, Yogyakarta \\ ${ }^{2}$ Fakultas Biologi Universitas Gadjah Mada, Yogyakarta \\ ${ }^{3}$ Jurusan Perikanan, Fakultas Pertanian Universitas Gadjah Mada, Yogyakarta \\ E-mail: hessbio@yahoo.com*Penulis untuk korespondensi
}

\begin{abstract}
This research was aimed to know the change in testoterone content on male individuals, also progresterone content on female individuals and the correlation among with Gonado Somatic Indices (GSI) and maturity content. Fish samples were collected monthly on the period of June 2009-May 2010, using simple random sampling. Hormone measurement was performed using ELISA method. Data analysis come from 120 female and 120 male individuals, including the ' $F$ ' test on the change of testosterone and progesterone, GSI and gonad maturity once a month during aperiod of the reproduction cycle. Also the correlation test among testoterone and progresterone content, with GSI and gonad maturity. The result showed, that the testosterone content on male individuals and also progesterone content on females individuals were changed during one year of the research period. The range testosterone content from $0.10-0.35 \mathrm{ng} / \mathrm{mL}$, while range progesterone from $0.25-0.60 \mathrm{ng} / \mathrm{mL}$. The highest content of testoterone was $0.203 \mathrm{n} \mathrm{g} / \mathrm{mL}$ and $0.224 \mathrm{n} \mathrm{g} / \mathrm{mL}$, found in September-October, and also the highest content of progresterone, was $0.645 \mathrm{~g} / \mathrm{mL}$ dan $0,091 \mathrm{n} \mathrm{g} / \mathrm{mL}$. Testoterone content and GSI showed positive significant correlation. A similar correlation was also observed between progesterone and GSI; testoterone and gonad maturity, and also between progresterone content and gonad maturity.
\end{abstract}

Keywords: Red cheek barb, Gonado Somatic Indices, gonad maturity, testosterone, progesterone

\section{Abstrak}

Penelitian ini bertujuan mengetahui perubahan kadar hormon testosteron pada ikan jantan dan hormon progesteron pada ikan betina, serta korelasinya dengan Indeks Gonado Somatik (IGS) dan Tingkat Kematangan Gonad (TKG). Sampel ikan diperoleh setiap bulan, selama Juni 2009-Mei 2010, menggunakan teknik simple random sampling. Pengukuran hormon dilakukan dengan metode ELISA. Analisis data dilakukan terhadap 120 ekor ikan jantan dan 120 ekor ikan betina, meliputi uji ' $F$ ' terhadap perubahan kadar testosteron dan progesteron, IGS dan TKG setiap bulan selama satu siklus reproduksi. Selain itu, dilakukan analisis korelasi antara kadar testosteron dan progesteron dengan IGS dan TKG. Hasil penelitian menunjukkan bahwa kadar testosteron dalam darah ikan brek jantan dan kadar progesteron dalam darah ikan brek betina selama satu tahun penelitian mengalami perubahan. Kadar testosteron memiliki kisaran antara 0,10-0,35 ng/mL, sedangkan kisaran progesteron antara $0,25-0,60 \mathrm{ng} / \mathrm{mL}$, Puncak tertinggi kadar testosteron sebesar $0,203 \mathrm{n} \mathrm{g} / \mathrm{mL}$ dan $0,224 \mathrm{n} \mathrm{g} / \mathrm{mL}$ terjadi pada bulan September-Oktober, demikian pula puncak tertinggi kadar progesteron sebesar $0,645 \mathrm{~g} / \mathrm{mL}$ dan $0,091 \mathrm{n} \mathrm{g} / \mathrm{mL}$. Korelasi kadar testosteron dengan IGS adalah positif nyata, demikian pula kadar progesteron dengan IGS. Korelasi kadar testosteron dengan TKG positif, demikian pula kadar progesteron dengan TKG.

Kata kunci: ikan brek, Indeks Gonado somatik, Tingkat kematangan Gonad, testosteron, progesteron 